\title{
Perceptions about Copyright of Digital Content and its Effects on Scholarship: A South African Perspective
}

\author{
Charles A. Masango \\ Department of Research \& Innovation, University of Cape Town, South Africa
}

This paper examines the different layers of protection that exist in digital content and how users and corporate rights holders of information interpret the different protections. From a South African perspective, this paper analyses librarians', managers' of consortia, informed users' and corporate rights holders' perceptions and misconceptions on the interpretation of copyright protection with regard to digital content.
It discusses the effects on the advancement of scholarship implied by the interpretations on copyright accorded by librarians, users and corporate rights holders to digital content. It concludes that in order to better access digital content to promote scholarship, the education of what copyright protects and knowledge of the terms and conditions of licensing agreements is necessary.

\section{Introduction}

Copyright is a procedure whereby the originator of a recorded work acquires a series of rights over the work created, including copying, publishing, performing, broadcasting and adaptation (Prytherch 2000,186). The aim of this paper is to show how some librarians, managers of consortia, informed users and corporate rights holders - the respondents in an investigation - have a disjointed understanding of the protection that copyright accords to digital content. From a South African viewpoint, this paper examines whether the interpretations accorded by the respondents on the type of protection that copyright confers on literary works has affected the application of the fair dealing exemption and interlibrary loan (ILL) services on digital content. The fair dealing exemption is a 'provision in copyright law that allows one copy of otherwise protected works to be made for the purpose of criticism, review or private study' (Keenan \& Johnston 2000, 104). Interlibrary loan is 'the lending and borrowing of items between libraries at the request of a patron' (Croft
$2005,42)$. In order to examine the interpretations or perceptions of the different groups, the paper first examines the different layers of protections that exist in digital content. Second, the paper examines through an empirical survey, the perceptions of the respondents of what copyright protects, and examines the possible reasons for such perceptions. Third, the potential consequences that the perceptions may have on the fair dealing exemption and ILL in promoting scholarship are discussed. The paper finally attempts to propose possible solutions that would assist in eliminating any false perceptions on the limits of copyright on literary works.

\section{Digital content protections}

Digital content is increasingly protected by multiple layers of intertwined legal and technological devices - copyright law, licensing agreements, software and hardware management systems and criminalising anti-circumvention laws. A technical barrier in the form of a Digital Rights Management System (DRMS), which is also protected by anti- 
circumvention clauses, protects digital content. In the digital environment, there are basically four types of protection. These are copyright, licences, DRMSs as well as anti-circumvention laws. Copyright protects digital content, as copyright is a procedure whereby the originator of a recorded work acquires a series of rights over the work created. Also, partly because of the advantages and convenience of digital information, access to content is, in practice, governed most directly by access licences (McCracken 2004, 122). The access licence is a form of contract between the library and a vendor, which is normally written by the vendor, 'with contract terms favouring the vendor' (Wyatt 2005, 164).

The technical protection in the form of various kinds of DRMSs, also known as automated rights management (ARM), is another layer of protection of digital content. This is because DRMSs seek to prevent unauthorized copies of copyrighted materials being made and can restrict copying if payment is not made. The DRMS that is buried within the digital code of copyrighted material has the ability to allow copies of copyrighted materials to be made upon payment, or to charge 'micropayments' for each small use of the copyrighted material (Liebowitz 2002, 16). Also, the DRMS regulates access to digital content (Muir 2003, 34). It controls access to digital content, prevents unauthorized copying of digital content, identifies digital content and those who own licences in them, and ensures that the identification data are authentic (Bygrave 2002).

Although the DRMS by its own merit protects digital content, the DRMS is fortified because nations such as the United States of America, Australia and the United Kingdom have, in addition, instituted anti-circumvention clauses in their copyright acts to protect the DRMS. The anti-circumvention clauses prohibit breaking of a security arrangement to access digital content (Braunstein 2000). The United States of America first introduced the anti-circumvention clause in the Digital Millennium Copyright Act (DMCA) 1998 in section 1201 (DMCA 1998), and nations such as Australia and the United Kingdom followed suit. The Australian Digital Agenda Act 2000 emulated the DMCA 1998 by instituting section 116A that forbids any form of circumvention (Lahore \& Rothnie 2004, 51 615). In the United Kingdom, just as in USA and Australia, section 296 of the Copyright,
Designs and Patents Act 1988 forbids circumvention of digital content (United Kingdom Copyright, Designs and Patents Act 1988 (c.48) 2000).

Notwithstanding that licences, DRMSs and anticircumvention clauses protect digital content, the content is also protected by copyright. Hence, digital content is protected by copyright notwithstanding that it is in digital format. Certain users and corporate rights holders, who know what copyright is meant to protect, share this view while others do not, as we shall see while examining the responses from the respondents in an empirical survey that was conducted in South Africa.

\section{Perceptions of copyright protection in the digital environment}

In South Africa, the author conducted an empirical survey. Following the survey, which probed among others whether licences that institutions typically sign with overseas vendors for access to database resources might inhibit access for some categories of library users who would in the past have had little or no difficulty, some conflicting perceptions were revealed about what copyright protects. When the respondents were questioned about copyright and licensing agreements, it was shown that there is a high level of ignorance among most of them about the laws of copyright.

In the survey that was conducted, the research approach was qualitative. The aim was to explore a particular phenomenon in depth that could only be obtained through the collection and analysis of subjective data from the selected participants involved in the process under investigation (Shenton \& Dixon 2004, 1). The study population were acquisitions and reference librarians, consortia managers, and informed users as well as corporate rights holders. What guided the pre-selection mechanism in this study was first to identify and interview librarians broadly representative of university libraries in South Africa. The Universities of Cape Town, Stellenbosch and the Western Cape were chosen. The University of Cape Town (UCT) represents a previously advantaged Englishspeaking institution, the University of Stellenbosch represents a formerly Afrikaans institution and the University of the Western Cape represents a formerly disadvantaged institution. Other selection criteria were those who possibly sign or negotiate licensing agreements for tertiary institutions 
(managers of consortia); those who are presumably knowledgeable with the effects that licensing agreements have on scholarly communication (informed users); and those who supplied the digital content that is accompanied by licensing agreements to the tertiary institution (corporate rights holders: vendors).

The pre-selection approach enabled the researcher to select 106 respondents. The total number of respondents interviewed was 58 i.e. $55 \%$. The other 48 , i.e. $45 \%$, were not interviewed because they declined to be interviewed for reasons such as lack of time and interest. Among the interviewed respondents were 13 acquisitions librarians, 11 reference librarians, 23 informed users and 5 rights holders.

The interview was the main instrument used in the survey. The researcher administered the interviews by visiting the respondents in their respective places of work, as well as in conference venues to conduct the interviews. As there were five different groups to be interviewed, five different sets of questions were formulated for the groups. Some of the questions were however addressed to all four groups. In order to obtain the perceptions of copyright protection in digital content, the acquisitions and reference librarians, users and managers of consortia were asked to respond to the following question:

- What in your view is the nature of the relationship between copyright law and digital licensing agreements?

The rights holders on the other hand were asked to respond to the following questions:

- Do you see a future for copyright?

- What do you believe will best protect your digital information? Is it the licensing agreement, copyright or some combination of the above?

With regard to communication of licensing agreements, the acquisitions and reference librarians, as well as managers of consortia were asked to respond to the following questions:

- How do librarians communicate information about licensing agreements to each other and to users?

- How do consortia communicate information about licensing agreements to their members and or to users?

The acquisitions and reference librarians were asked to respond to the following question:

- Do librarians inform users about licensing agreements?
The interviews were analysed to establish patterns in the perceptions of respondents about copyright of digital content in South Africa. Grounded theory was used in analysing the information. In grounded theory

[...] analysis emphasizes the conceptualisation of the data, and the generation of conceptually abstract categories grounded in the data, working towards a condensed, abstract and emerging interpretation of what is central in the data. It uses the power of abstract theory to transcend the empirical data, and to connect seemingly disparate phenomena. [...] the outcome of grounded theory analysis is an abstract but grounded concept (the core category) the development of which constitutes a substantive theory of the phenomenon being studied (Punch 1998, 218).

\section{Differentiation between copyright and digital content}

Following the survey, it emerged that several acquisitions and reference librarians, managers of consortia, informed users and a handful of rights holders wrongly believe that there are different laws governing print and digital information. Several of them showed their ignorance in the survey when asked about the nature of relationship between copyright law and digital licensing agreements. They were of the opinion that copyright law and licensing agreements are two different laws, one dealing with print information while licensing agreements deal with digital information. One of the librarians even put it bluntly (and incorrectly) by saying that there was no link between copyright laws and licensing agreements because copyright law protects print material and a licensing agreement protects electronic resources. Rights holders were no better informed. One gave an ambiguous response, going some way towards confirming the suspicion that at least some rights holders are unaware that copyright protects digital content. When rights holders were asked about the future of copyright, a respondent said that copyright laws should be incorporated or reflected in the licensing agreement.

Following the responses from the survey, it can be argued that the reason for the failure by some respondents to recognise that copyright protects all forms of information may be the idea that licences apply to digital resources and copyright therefore only applies to printed sources. This is because licensing agreements dictate terms and 
conditions of access to digital content. McCracken $(2004,122)$ corroborates this opinion with the statement "when physical books are replaced by works presented in soft copy and delivered by digital readers or via digital networks, then access to such works is determined by rights licensing and trading."

Furthermore, this misconception may have been grounded in erroneous interpretations of the views expressed by some scholars (Litman 1996; Loundy 1995; Samuelson 1994) that digital tech nology raises new issues that cannot be addressed by current copyright law. Digital technology raises issues of electronic reproduction, scanning and electronic storage, transmission and distribution, manipulation and adaptation, as well as the basic licence to browse (Baldwin 2001). According to Trosow $(2003,217)$ "contemporary advances in information technology have enabled the enhanced production, dissemination, use, and transformation of information resources to an extent unimaginable a quarter of a century ago." It can be argued that the views expressed by these scholars may have been interpreted erroneously. Copyright protects digital content because the content is in literary form.

It can be said that the perceptions and misconceptions of the respondents in the survey are not entirely surprising. Malhotra $(1995,37)$ argues that, "sometimes even editors and publishers are unaware of the laws of copyright, not to speak of the general public." This is corroborated in South Africa by the Human Sciences Research Council (HSRC) report of 1987 that revealed that most teaching staff was not familiar with copyright restrictions (HSRC Education Research Programme 1987).

On the other hand, it can be argued that the survey showed that many of the respondents were unaware of the laws of copyright probably because they have had no formal tuition informing them of what copyright comprises. During the interview, a librarian said "following the type of questions you are asking. I will strongly recommend that you come and give us a talk on these issues." Most of the librarians and users of digital content are not versed in the content of the licensing agreements, most of which carry the copyright symbol at the end of the terms and conditions of the agreements. According to the survey, when acquisitions and reference librarians, as well as man- agers of consortia were asked how they communicate licensing agreements to each other and to users, and acquisitions and reference librarians were asked how they inform users about licensing agreements, some unsatisfactory responses were conveyed. Most of the responses to this question showed that the main channel in communicating licensing information is from acquisitions librarians to the reference librarians to the users of digital content. It was also revealed that not all acquisitions librarians are familiar with licensing agreements. Furthermore, the survey showed that users of digital content are unaware of the terms and conditions of licensing agreements. The electronic resources librarians do not find it necessary to communicate information about licenses to the users of the information. The users are only told about the terms and conditions in a licensing agreement on request.

However, although many respondents were unaware that copyright exists in digital content, most rights holders and a handful of librarians and users knew this. Such a key belief was held by those rights holders who had read their own licences, since most such agreements conclude that any person who defaults on the agreement in defined ways may be in contravention of copyright law. Most rights holders when they were asked whether there is a future for copyright, showed a good knowledge of how copyright exists in digital content. A rights holder said there was a future for copyright, as it is always there to protect intellectual property rights of persons and organizations. Most of the rights holders substantiated their arguments about copyright when answering questions on what they believe will best protect digital information, whether it is licensing agreement, copyright or some combination of the two. The rights holders said licensing agreements are to guide the use of the databases that have been subscribed to by the institution and not to protect copyright. This is because copyright already exists in the digital information, as it is an intellectual property of an organization or person. It can be argued that most rights holders were better aware that copyright protects digital information because they were out to protect their interests. There were however, a few users and librarians, who knew that copyright law applies to digital content, because they recognised that copyright is applicable in both print and digital information. 
They substantiated this view by saying that copyright guides the ownership of the materials in digital and print information.

\section{Fair dealing exemption, ILL and their impact on scholarship}

It can be argued that since many respondents to the survey are ignorant that copyright exists in digital content, this perception may inhibit access to digital content and hence scholarship. For example, the librarians may fail to reflect on certain copyright guidelines such as the fair dealing exemption or fair use that apply to literary works because it is not explicitly mentioned in a licensing agreement. In exercising their duties as custodians of digital content, they may wrongfully refuse to accept the application of the copyright fair dealing exemption that permits copying of information for scholarship just because they believe that copyright was established to deal with the products of the printing press (Hofman 1999, 12) and not to deal with digital content. Hence, in instances where librarians come across students copying digital content within the ambit of the fair dealing exemption, they may interpret such behaviour as wrong and possibly stop the students from continuing. In a scenario of this sort, it can be argued that the behaviour of the librarians would be wrong because copyright that protects both print and digital content permits copying for scholarship. According to Amen, Keogh \& Wolff $(2002,24)$, the fair dealing exemption permits free copying of information provided the copied information is used for research, criticism, teaching, and under certain circumstances that will not interfere with the legitimate rights of the copyright holders. The South African Copyright Act 98 of 1978, stipulate in sections 12(1):

Copyright shall not be infringed if a literary or musical work is used solely, and then only to the extent reasonably necessary -

(a) for the purposes of research or private study by, or the personal or private use of, the person using the work;

(b) for the purposes of criticism or review of that work or of another work; or

(c) for the purpose of reporting current events -

(i) in a newspaper, magazine or similar periodical; or

(ii) by means of broadcasting or in a cinematograph film:
Provided that, subject to the provisions of section 13, the expression 'used' shall not be constructed as authorizing the making of a copy of the whole or a substantial part of the work in question. Provided further, in the case of paragraphs (b) and (c) (i), that the source shall be mentioned, as well as the name of the author if it appears on the work (South Africa Statutes 2000, 220; Copeling 1978, 41).

It can be said that since the wording of the fair dealing exemption as stipulated in the South African Copyright Act 98 of 1978 does not distinguish between print and digital literary works, the fair dealing provision applies to all literary works both print and digital.

Furthermore, the outcome of some inaccurate perceptions about what copyright protects, brought about because librarians are not familiar with the content of licensing agreements may also inhibit access to digital content and thus to scholarship. Librarians may refuse to satisfy an ILL request for digital content. The ILL process "allows the owner of a copy of a copyrighted item to lend, rent, resell, or dispose of that copy as desired" (Croft 2005, 42). The lack of knowledge about licensing agreements may hence allow librarians to refuse to satisfy an ILL request on the pretext that the agreements do not permit ILL. This is likely to occur even when certain agreements permit ILL. For example, ScienceDirect permits ILL (ScienceDirect Subscriber Licence 1999). In the survey, ILL librarians said they would not send any information requested from an unauthorized user, if such information could only be found in electronic databases because licensing agreements do not permit ILL. It can be said that a decision of this sort would be wrong and detrimental to scholarship if requested information is contained in a ScienceDirect database. The ignorance of the librarians on terms and conditions in licensing agreements would deny access to information that is contained in a database that permits ILL to a genuine requester and user of information. This would affect scholarship, as the user would not be served with the needed information for him or her to use in advancing scholarship.

Also, since users can only be told about the terms and conditions in a licensing agreement on request, this may prevent users from accessing digital content and thereby inhibiting them advancing their own scholarship. It is through the information that they access that they are able to produce new information (Williams 2002, 143). It 
can be argued that by users not being aware of the terms and conditions of licensing agreements, may allow them to claim certain rights that are not permitted by an agreement on how they can use a particular digital content. For example, they may decide to give their passwords to an unauthorized user of the digital content on the pretext that they do not know that it is not allowed by the agreement. Where a user does this and it is against the terms and conditions of licensing agreements, the rights holders may at a certain point decide to sue an institution for infringement of the agreement or possibly terminate access to the information for the institution. Although to the best of my knowledge, a rights holder has not sued any institution for a user's infringement of licences in South Africa, it is possible for rights holders to terminate access to digital content as certain licensing agreements permit such measures. For example, the JSTOR licensing agreement expressly states:

Any use of the JSTOR archive beyond the scope of the Licence, knowing use of the password of another, or any fraudulent, abusive, or otherwise illegal activity, may be grounds for termination of your account, or termination of access to JSTOR from your IP address, without notice and at JSTOR's sole discretion (JSTOR licensing agreement 2005)

\section{Possible solutions to misconceptions?}

Academic institutions in South Africa are subject to copyright norms as stipulated by the 1978 Copyright Act. Although section 2(1) of the Act states that copyright protects original works, the Act does not stipulate that institutions should make sure that librarians and users are versed with aspects of copyright. Notwithstanding this omission, it may be the duty of institutions to educate its librarians who are custodians of information and users of information on the laws of copyright as stipulated in the copyright act. This is because institutions may be held liable for copyright infringement committed by faculty and staff, and by students if it is proven that the institution did nothing to inform users about copyright issues (Harper 2004).

In educating librarians and users about copyright, institutions should set up courses on copyright-related issues to be taught by legal experts, librarians and other stakeholders who are versed in copyright issues in the institutions. Also, institutions should lobby and convince members of in- stitutional committees that knowledge of copyright through short courses is germane because it may curb possible infringement of copyright and suits from rights holders when a copyright infringement is committed. In this way, proposals for courses on copyright could be expected to receive serious attention from prominent members of committees. Furthermore, institutions should work closely with the convenors of the short courses in order to ensure that practical problems related to copyright issues are dealt with in the short courses.

With regard to the dissemination of licensing terms and conditions, the non-communication of licensing terms and conditions to users of digital content is a serious mistake on the part of subscribers of the information. This is because "educating end-users about licensing terms is an on-going systematic activity at most academic research institutions [...]" (Emery 2005, 27). Where users of digital content are left to find out about terms and conditions in licensing agreements, they may find the process inconvenient or tedious. Thereby they might be tempted to use the information as they please on the pretext that they have not been told how to use the information. Where this takes place and it is proven that a user has infringed an agreement, rights holders may terminate all users' access to the information if the agreement permits such termination, thereby inhibiting other users' access to such information to be used to promote scholarship. Hence in order to avoid this, licensing agreements should not be filed away centrally. Reference librarians should have copies of licensing agreements and should be abreast with the conditions. This would prevent them from giving out false information about licensing agreements.

In educating users about terms and conditions of licensing agreements, brochures should be prepared and placed at the entrance of the library informing users to be aware of terms and conditions of licensing agreements on digital information and possible penalties for those who infringe the agreements. This might encourage users to look for notices that carry specific information about particular licensing terms and conditions in the library for accessing the digital content. Furthermore, notices should be placed in front of computers that contain digital content indicating that only authorized users are to access digital content and if any user needs to know more about the licensing 
agreements, the user should contact the reference librarian. This automatically informs users where they can get further information about licensing terms and conditions. Subscribers should not first wait for end users to request information about terms and conditions in a licensing agreement before providing such information. The terms and conditions can be made known to the end users by placing such conditions on websites. Libraries should scan licences and provide a link to the scanned contract for the user from their online public access catalogue (OPAC). The terms and conditions of the licences should be made available on all Web pages that link to electronic resources (Emery 2005, 29). Furthermore, the terms and conditions should be placed and made available in such a manner that any one who wants to use the digital content must first read and click on an icon that reads 'I accept the terms and conditions' before the user is allowed access to the digital content. Where this is done, there may be some degree of certainty that whoever is using digital content must have noted the terms and conditions and it will be assumed that such a user will have read the conditions.

\section{Conclusion}

In view of the perceptions and demonstrated misconceptions of respondents about the type of protection that copyright confers on literary works, it seems appropriate to educate and communicate licensing terms and conditions to all who directly and indirectly access digital information. Where librarians and users are educated and are abreast of what copyright protects, it may help to curb misconceptions and lead to improved access to digital content that will help in promoting scholarship. It has been shown that most librarians, users, managers of consortia and some rights holders in the survey wrongly believe that there are different laws governing print and digital information. They were under the impression that copyright law deals with print information while licensing agreements deal with digital information. It can be argued that if and when most librarians, users, managers of consortia and rights holders are formally educated on what copyright does and does not protect, it is likely that the misconception among these groups would no longer prevail and may help to improve access to information and scholarship.

Furthermore, since the survey showed that most librarians and users of digital content are not familiar with the content of licensing agreements, it would be preferable for all those who interfere with digital content to be abreast with licensing terms and conditions in order to promote scholarship. This is to curb the global perceptions and misconception about licensing agreements, as licenses are not consistent in their approach to copying (International Coalition of Library Consortia 2001).

In order to better access digital content to promote scholarship, the education of what copyright protects and knowledge of the terms and conditions of licensing agreements is necessary. However, not until librarians and users of digital content are properly informed of what copyright protects and about licensing agreements, will we have developed a functioning channel through which scholars can better access digital content to promote scholarship.

\section{References}

Amen, K., T. Keogh and N. Wolff. 2002. Digital copyright: A tale of domestic discord, presented in three Acts. Computers in libraries 22(5): 22-27.

Baldwin, C. 2001. Electronic copyright: A publisher's view. Available at URL: http://users.aber.ac.uk/mdt/ copyrite/superj.htm [viewed July 25, 2006].

Braunstein, P. 2000. Cracking DVD Code: MPAA's dragooning of Norwegian teen raises hackers' hackles. LA Weekly 11-17, 2000. Available at URL: http: / / www.laweekly.com/ink/00/12 / cyberbraunstein.php [viewed July 25, 2006].

Bygrave, L. A. 2002. The technologisation of copyright: implications for privacy and related interests. European intellectual property reviews 24(2): 51-57. Available at URL: http://folk.uio.no/lee/publications / technologisation_copyright_eipr_final.pdf [viewed July 25, 2006].

Copeling, A.J.C. 1978. Copyright and the Act of 1978. Durban: Butterworths.

Croft, J. B. 2005. Interlibrary loan and licensing: tools for proactive contract management. Journal of library administration 42(3/4): 41-53.

Digital Millennium Copyright Act. 1998. The Digital Millennium Copyright Act of 1998: Copyright Office Summary. Pub. L. No. 105-304, 112 Stat. 2860 (Oct. 28, 1998). Available at URL: http://www.loc.gov/ 
copyright/legislation/dmca.pdf [viewed July 25, 2006].

Emery, J. 2005. Is our best good enough? Educating end-users about licensing terms. Journal of library administration 42(3/4): 27-39.

Harper, G. 2004. Copyright and the university community: implementing a comprehensive copyright policy. Available at URL: http://www.utsystem.edu/ogc/ intellectualproperty/admin3.htm [viewed July 25, 2006].

Hofman, J. 1999. Cyberlaw: a guide for South Africans doing business online. Cape Town: Ampersand Press.

HSRC Education Research Programme, No. 8. 1987. Copyright and education and training in the Republic of South Africa. Pretoria: Human Sciences Research Council.

International Coalition of Library Consortia. 2001. Statement of current perspective and preferred practices for the selection and purchase of electronic information: Update No.1: new developments in e-journal licensing. Available at URL: http://www.library.yale.edu/consortia/ 2001currentpractices.htm [viewed July 25, 2006].

JSTOR terms and conditions. 2005. Available at URL: http://www.jstor.org/about/terms.html [viewed July 25, 2006].

Keenan, S. and C. Johnston. 2000. Concise dictionary of library and information science. $2^{\text {nd }}$ ed. London: Bowker Saur.

Lahore, J. and W.A. Rothnie. 2004. Digital Agenda - The Copyright Amendment (Digital Agenda) Act 2000. Sydney, Australia: Butterworths. 1-Commentary.

Leaffer, M. 1989. Understanding copyright law. New York: Matthew Bender.

Liebowitz, S. 2002. Policing pirates in the networked age. Policy analysis 438, May 15, 2002. Available at URL: http://www.cato.org/pubs/pas/pa438.pdf [viewed July 25, 2006].

Litman, J. 1996. Revising copyright law for the information age. Available at URL: http:/ / www.law.cornell.edu/ commentary/intelpro/litrvtxt.htm [viewed July 21, 2005].

Loundy, D. 1995. Revising the copyright law for electronic publishing. Available at URL: http://www.loundy. com/Revising-HyperT.html [viewed July 25, 2006].
Malhotra, D. N. 1995. Copyright: a perspective from the developing world. In Copyright and development: inequality in the information age. Edited by Philip G. Altbach. Boston: Bellagio Publishing Network. 4: 35-48.

McCracken, R. 2004. Agreements, user licences and codes of practice. In Staying legal: a guide to issues and practice affecting the library, information and publishing sectors. $2^{\text {nd }}$ ed. Edited by Chris Armstrong \& Laurence W. Bebbington. London: Facet Publishing. 122-139.

Muir, A. 2003. Copyright and licensing for digital preservation. Library + information update 2(6): 34-36.

Prytherch, R. 2000. Harrod's librarians' glossary and reference book. $9^{\text {th }}$ ed. Aldershot: Gower.

Punch, K.F. 1998. Introduction to social research: quantitative and qualitative approaches. London: Sage.

Samuelson, P. 1994. Copyright, digital data, and fair use in digital networked environments. Available at URL: http: / / www.lexum.umontreal.ca/conf/ae/en/ samuelson.html [viewed July 25, 2006].

ScienceDirect Subscriber Licence. 1999. Available at URL: http:/ / www.griffith.edu.au/ins/collections / ejournal/elsevier.pdf [viewed July 25, 2006].

Shenton, A.K. and P. Dixon. 2004. Debates and paradoxes surrounding the use of qualitative methods. Education for information 22(1): 1-12.

South Africa Statutes. 2000. Copyright Act 98 of $1978.10^{\text {th }}$ ed. Cape Town: Juta Law. 2:220-234.

Trosow, S.E. 2003. The illusive search for justification theories: copyright, commodification and capital. Canadian journal of law and jurisprudence 16(2): 217241.

United Kingdom Copyright, Designs and Patents Act 1988 (c.48). 2000. Miscellaneous and general: devices designed to circumvent copy-protection. Available at URL: http://www.hmso.gov.uk/acts/acts1988/ Ukpga_19880048_en_21.htm\#mdiv296 [viewed July $25,2006]$.

Williams, S. 2002. Free as in freedom: Richard Stallman's crusade for free software. Sebastopol: O'Reilly \& Associates.

Wyatt, A. M. 2005. Licences, the law, and libraries. Journal of library administration 42(3/4): 163-176.

Editorial history:

Paper received 22 December 2006;

Accepted 9 February 2007 